\title{
Improving 7th Grade Students' Epistemological Beliefs by Epistemologically Enriched Argumentation Model
}

\author{
Oktay Kızkapan ${ }^{1 *}$, Oktay Bektaş ${ }^{2}$
}

\author{
${ }^{1}$ Nevsehir Haci Bektas Veli University, TURKEY \\ ${ }^{2}$ Erciyes University, TURKEY \\ *Corresponding Author: okizkapan@nevsehir.edu.tr
}

Citation: Kızkapan, O., \& Bektaş, O. (2021). Improving 7th Grade Students' Epistemological Beliefs by Epistemologically Enriched Argumentation Model. Pedagogical Research, 6(3), em0095. https://doi.org/10.29333/pr/10949

\section{ARTICLE INFO}

Received: 4 Nov. 2020

Accepted: 24 Jan. 2021

\begin{abstract}
This study aims the aim of this study was to investigate the effect of Toulmin argumentation model (TAM), epistemologically enriched Toulmin argumentation model (EETAM), and method suggested in Turkish Science Curricula on the epistemological beliefs of 7 th grade students and their views on this effect. In this context, while the students in TAM group learned seventh grade structure and properties of matter unit through TAM; the students in EETAM group learned seventh grade structure and properties of matter unit through TAM and then had explicit discussions about epistemological belief dimensions. In the comparison group, students fallowed national science curriculum and learned the same science topic through the method suggested in curriculum. Students' epistemological beliefs were determined with epistemological belief scale. Also, students' opinions about the effect of TAM and EETAM were determined by semi-structured interviews. Therefore, embedded design of mixed method researches was used. Two experimental and one comparison groups were included. The sample of the study consisted of 98 students studying in a public school in Kayseri, Turkey. As a result of the study, there was a significant difference only between the EEAM group and the comparison group in terms of epistemological beliefs. The same results were reached in the qualitative findings. Therefore, it can be said that explicit discussions on epistemological beliefs is more effective than inquiry-based teaching and method suggested in Turkish national science curriculum. Thus, results expose that explicit teaching of epistemological beliefs helps students better understand epistemic nature of scientific knowledge and learning.
\end{abstract}

Keywords: epistemological beliefs, argumentation, mixed method

\section{INTRODUCTION}

Epistemological beliefs have had a significant impact on students' understanding. (Schommer, 1990). Recognition of the importance of epistemological beliefs has started with Perry's work. The studies led by Perry inspired many researchers and paved the way for the creation of different models on this issue (Schommer, 1990). In 1950, Piaget pioneered the studies on epistemological beliefs by using the concept of genetic epistemology to explain the theory of cognitive development (Hofer \& Pintrich, 1997).

As an issue in philosophy, "epistemology is concerned with the origin, nature, boundaries, methods and justifications of knowledge. The term "epistemic," by contrast, relates to knowledge more generally, and the conditions for acquiring it" (Hofer, 2002). On the other hand, studies on epistemological beliefs have considered how people perceive knowledge and learning as a research topic (Rosenberg et al., 2006). From a psychological and educational perspective, personal epistemology focuses on how individuals develop knowledge and how they use it to understand the world. Therefore, personal epistemology includes beliefs about what knowledge is (definition), how it is built, how it is evaluated, where it is found, and how it emerges (Hofer \& Pintrich, 2012).

It is seen that the first studies in this field are in the form of questionnaires and in-depth interviews conducted with students at Harvard University focusing on the issues of students' development (Schommer, 1990). Perry (1968) put forward the idea that the students go through the epistemological developmental stages. He stated that students perceive the knowledge as certain true or false in the early stages of this developmental process and that the authority knew the correct answer. However, as students reached higher levels of development, they thought that there could be multiple possibilities of knowledge and that people should have a strong but changeable commitment to ideas.

This research is produced from the doctoral dissertation prepared by the first author in the advisory of the second author. 
Despite the idea of one-dimensional and constant progressive stages of epistemological beliefs advocated by Perry and some other researchers, Schommer (1990) considered epistemological beliefs as a system of thought that consists of several independent dimensions. Schommer (1990) argues that epistemological beliefs are too complex to be one-dimensional, arguing that there are at least five dimensions of epistemological beliefs and named these dimensions as simple knowledge, certain knowledge, omniscient authority, innate ability and quick learning. Schommer $(1990,1993)$ explained the varying views in these dimensions from naive to sophisticated as follows;

- Simple knowledge: Knowledge is compartmentalized or knowledge is highly integrated and interwoven.

- Certain of Knowledge: Knowledge is not absolute or knowledge is constantly evolving.

- Omniscient Authority: Knowledge is not handed down by omniscient authority or knowledge is also reasoned out through objective and subjective means.

- Innate Ability: Ability to learn is genetically predetermined or ability to learn is acquired through experience and hard work.

- Quick Learning: Learning is quick or not-at-all or learning occurs in a gradual process.

In the field of science education, there are important studies on the nature of epistemological beliefs, their relationship with learning and how they are affected by the classroom environment (e.g., Bektaş, 2011; Hofer \& Pintrich, 1997; Pamuk, 2014; Sandoval, 2003; Saylan Kirmizigul \& Bektas, 2019; Tsai, 1998; Yerdelen Damar, 2013). Students' epistemological beliefs affect their approaches, knowledge, working methods and reasoning abilities towards an activity or task (Hammer \& Elby, 2002; Hogan, 1999; Rosenberg et al., 2006). Therefore, students' epistemological beliefs should be taken into consideration in learning and teaching processes in science classes.

In Turkey, in the previous (MoNE, 2013) and current science education curricula (MoNE, 2018), it is seen that learning methods such as problem-based, project-based, argumentation, cooperative learning is recommended where students are more active. Teachers were asked to provide comfortable environments in which students could express their ideas, support these ideas using different reasons, and develop opposing arguments to refute others' claims. It was stated in the science curricula that in the oral or written arguments, teachers should guide students to propose claims, warrants, backings, and rebuttals based on the data. It was also stated that inquiry processes will be considered not only as experiments and discoveries, but also as explanations and arguments (MoNE, 2013). Thus, in science education, argumentation is not a luxury, but it is completely necessary to consider the essence of science (Erduran, 2007).

Argumentation is a discourse pattern which is instrumental in the advancement of scientific knowledge (Kitcher, 1988) as well as an essential element of scientific discourse (Pera, 1994). Thus, argumentation reflects the nature of science as inquiry and discussion, guides students through activities, and functions as a metacognitive support that asks students to reason about their data (Akkuş et al., 2007). According to Munford \& Zembal-Saul (2002), students who learn by argumentation have the opportunity to think both about the concepts in science and also about science, and can try both the rational and procedural applications of scientists. Argumentation enables learners to evaluate knowledge and themselves, while supporting learners to develop different ways of thinking. It also allows students to recognize the role of language, culture and social interactions in the structuring of knowledge. Finally, students who learn science concepts through argumentation are not only consumers of scientific knowledge, but also have experience of being the ones who reproduce this knowledge. It can be seen that the argumentations performed in educational settings are related to the cognitive ability, epistemology, motivation and knowledge of the subject. Therefore, it can be said that students' argumentation skills and epistemological beliefs are related and influence each other (Evagorou \& Osborne, 2009).

The use of scientific argumentation to establish theories about natural phenomena helps students to understand scientific processes and to practice them (Osborne \& Young, 1998). Toulmin (2003) made a crucial contribution to this aspect He changed the idea of the conventional inductive logic and developed a paradigm for people to argue in natural settings Toulmin introduced a model that describes functional relationships and has six elements of argumentation. In the field of science education, this model is accepted in a broad range (Giri \& Paily, 2020). Toulmin's argumentation model (TAM) is not limited to a debate involving two or more people, rather it is used for personal reasoning, at which an individual draws conclusions depends on the data available (Hitchcock, 2005). According to Toulmin, in order to prevent irresponsible claims, the claims should be supported with the relevant evidence. A claim is the conclusion of an argument in Toulmin's model. A person needs evidence to support it in order to make such an argument. In Toulmin's model, such information is called data. At least one warrant should be given in order to support the relationship between the data and the claim. Warrants are propositions which are used as explicit assumptions that serve as a connection between data and claims. Two others components of Toulmin model are qualifiers and rebuttals. The qualifier stands alongside the claim and shows the strength of the claim and it is concerned with the warrants and rebuttals. The last component of the model is backing, which represents the source of a warrant (de Oliveira Gabriel et al., 2020). A brief description of Toulmin's argument components is as follows (Magalhães, 2020).

- Claim: Proposal that supports, rejects or asks anything

- Data: Facts that support the conclusion

- Warrant: Statements that affirm a claim.

- Qualifier: Indication of strength of argument. Typically it is done by phrases such as necessarily or probably.

- Backing: Statements which restrict the strength of the argument or which propose conditions for the argument to be valid.

- Rebuttal: Statements which disprove an argument.

When the literature on argumentation is examined, TAM enable students to participate in cognitive and metacognitive processes, develop meaningful learning and communication skills, mobilize their critical thinking abilities, and understand science culture and develop science literacy (Jimenez-Aleixandre \& Erduran, 2007; Kuhn, 2005; Sandoval et al., 2019). 
TAM allows students to make sense of science concepts through research questions, explanations, testing claims and group discussions like a scientist based on the evidence. Therefore, we expect that, with the effective use of TAM, students will develop their beliefs in the dimensions of epistemological beliefs.

Studies in the literature show that the teaching methods increasing students' conceptual understanding may not have the same effect on their epistemological beliefs (Elby, 2001). Moreover, implicit teachings are not as much effective on developing students' epistemological understanding as explicit teachings of epistemological beliefs (Elby, 2001; Redish \& Hammer, 2009; Sandoval \& Morrison, 2003). When the relevant literature on this subject is examined, it can be said that the number of researches examining the effectiveness of explicit teachings by considering the personal epistemological beliefs of the students in science and other fields is limited (Yerdelen Damar, 2013). Although the theoretical frameworks underlying the researches are not explicitly declared, instructional design approaches provide clues as to which theoretical frameworks they support. In most of these studies, it is seen that the teaching plan to be implemented is based on the idea that the students hold consistent, stable and subject-independent epistemological beliefs (Hammer \& Elby, 2002). However, many studies in the literature (e.g., Lising \& Elby, 2005; Rosenberg et al., 2006; Sandoval \& Morrison, 2003) support that epistemological beliefs consist of consistent and more or less independent dimensions and are dependent on the subject (context) in accordance with the theoretical foundations of Schommer (1990).

Epistemology teaching should aim to activate and consolidate the individual's epistemological resources instead of abolishing the old beliefs in order to develop their epistemological understanding (Elby \& Hammer, 2010). When the studies carried out in this way were examined, most the studies emphasizing explicit epistemological teaching were conducted with university students. It is seen in the literature that most of the research on personal epistemology studies aimed to test the guidelines in educational psychology or similar courses and to develop students' epistemological beliefs (Yerdelen Damar, 2013). Therefore, further research is needed to clearly investigate the effects of epistemological teaching on science at middle school and high school level. In addition, only one study was reached which tested the effectiveness of explicit epistemological teaching focusing on the personal epistemology of Turkish students (Yerdelen Damar, 2013). In her study, the researcher reported that teacher-centered method is more effective in increasing the physics achievement of students with naive epistemological understanding. On the other hand, for students with sophisticated epistemological beliefs, epistemologically and meta-cognitively enriched constructivist teaching method (7E learning cycle) is more effective.

In the current study, Toulmin argumentation model is used to develop students' epistemological beliefs through explicit discussions on dimensions of epistemological beliefs after learning a science subject. In this context, during science lessons, students first learned the structure and properties of matter (SPM) unit through Toulmin argumentation model (TAM). Then, teacher started a new discussion session on epistemological beliefs. In this session, teacher initiated the discussion by asking a question about a dimension of epistemological beliefs. Students are asked to use what they have learned in SPM unit to justify their argument. In this way, modified version of Toulmin argumentation model is obtained. This modified version of model is named as epistemologically enriched Toulmin argumentation model (EETAM). In this respect, no study was found in the literature examining the effect of TAM to development of students' epistemological beliefs while teaching subject knowledge. Therefore, it is thought that this is an original study that synthesizes these three dimensions (Toulmin argumentation model, subject knowledge and epistemological beliefs) in the literature. It is thought that this study, carried out on these grounds, will contribute to the literature by providing experimental evidence on how Toulmin argumentation model enriched with the discussions on epistemological beliefs will improve students' personal epistemological beliefs.

Based on all these justifications, the aim of this study was to investigate the effect of TAM and EETAM on the epistemological beliefs of 7 th grade students and their views on this effect. On this context, to elicit the quantitative results, qualitative data are collected in the study. Therefore, this study is carried out based on two main research questions. These questions are as follows;

- What is the effect of Toulmin argumentation model (TAM) and epistemologically enriched Toulmin argumentation model (EETAM) on the epistemological beliefs of seventh grade students compared to national science curriculum?

- How are the opinions of students in the experimental groups about the effect of TAM and EETAM on epistemological beliefs?

\section{METHOD}

\section{Research Design}

In this research, mixed research method was applied. According to Creswell and Plano Clark (2015), in mixed method researches, researcher collects, analyses, integrates or combines quantitative and qualitative data in a single study or a multistage study. In this research, there are different research questions that require quantitative and qualitative data collection. In the quantitative part of the study, the effect of TAM and EETAM on the epistemological beliefs of students was compared to the current science curriculum. In the qualitative part, the students' opinions about the effect of TAM and EETAM on epistemological beliefs were tried to be determined based on students' views. Therefore, most appropriate design for the study is the embedded design, which is used in cases where a single data group is not sufficient to answer different types of questions. In the quantitative part of the study, a quasi-experimental design with pretest-posttest comparison group was used. In the qualitative part, a phenomenological design was used to determine the students' opinions about the effect of AM and EEAM on epistemological beliefs. 


\section{Population and Sample}

The target population of this study is all seventh-grade students in Kayseri, a major city in central Anatolia region of Turkey. The accessible population comprised all seventh-grade students in the fifth education zone of Kocasinan district of Kayseri. The research results will be generalized to the accessible population. The number of students attending seventh grade in the accessible population was 1052 students. In order to generalize the results of the study, researchers tried to reach $10 \%$ of the students in this accessible population. For this reason, it can be said that convenience sampling method is used and $10 \%$ rule is taken into consideration when determining the sample (Hill, 1998). The sample of the study consisted of three groups (two experimental and one comparison group) which are randomly selected from the 7th grade in a secondary school in Kocasinan district of Kayseri province in the 2017-2018 academic years.

A total of 98 students participated in this study. Among them, 34 of these students were in 7/A class (Experimental Group 1 (EG1), TAM group), 32 of them were in 7/D class (Experimental Group 2 (EG2), EETAM group) and 32 of them were in 7/C (Comparison group, National science program). While determining the experimental and comparison groups, one-way ANOVA was conducted to consider whether there was a statistically significant difference between the achievement pretest mean scores of the groups. Although there was no difference between the groups in terms of achievement pretest scores $(F(2,95)=.691, p>.05)$; in order to prevent a possible threat to internal validity, the class with highest average $(\bar{X}=8.68)$ was determined as the TAM group, the one with the lowest average $(\bar{X}=7.94)$ was determined as EETAM group, and the class with the medium average $(\bar{X}=8.41)$ was determined as comparison group. In this way, it is aimed to prevent a possible threat to internal validity.

\section{Study Group}

Qualitative data of the study collected from the students in the TAM and EETAM groups. Participants of the study were determined by using maximum variation sampling. Qualitative data of the research were collected by conducting semi-structured interviews with a total of 12 students, six from each experimental group. While determining these students, argumentation opinion scale was applied to the students. Two students who got low, medium and high scores from the scale were selected from each experimental group. At the end of the study, students' opinions about the effects of TAM and EETAM on epistemological beliefs were tried to be determined based on students' opinions. The names of the students in the TAM group were coded as Nur, Ata, Can, Ali, Efe and Ece, while the names of the students in EETAM were coded as Alp, Naz, Eren, Asu, Gül and Ahu.

\section{Data Collection Tools}

\section{Epistemological belief scale}

In this study, quantitative data were collected using the epistemological belief scale (EBS) developed by researchers as a result of literature review (Boz et al., 2011; Kızılgüneş et al., 2009; Pamuk, 2014; Schraw et al., 2002; Tucel, 2016). As a result of the literature review, a draft epistemological belief scale (DEBS) consisting of 64 items with five likert-type responses was developed by using the scales developed or adopted by different researchers (Özkan, 2008, Deryakulu \& Büyüköztürk, 2002; Schraw et al., 2002). In the scope of the pilot study, DEBS was applied to 700 students ( 2847 th grade and 416 th grade) studying in secondary schools. However, since the responses of 28 students were incomplete, these students were excluded from the study. Then, exploratory factor analysis (EFA) was conducted for construct validity. During EFA, some items $(5,13,14,16,17,18,23,26,27,39$, 54, 58, 59, 63 and 64. items) were removed from the scale because values were lower than .30 in the communalities table. Also, items 32, 33 and 44 were removed since they were cross loaded (Tabachnick \& Fidell, 2013). Lastly, it was seen that items in the scale were collected under five factors. However, since the reliability coefficient of the fifth factor was .149, items in this factor (6, $7,20,21,34,56,57$ and 62 . items) and some other items (1, 3, 4, 15, 19, 30, 41, 53. items) reducing the reliability of the scale were also removed from scale. EFA was run on the remaining 29 items. Based on the KMO value (.896) and significant value of Bartlett test of sphericity (.000), it is decided that sample size is adequate, the collected data were appropriate for the analysis and the scores obtained from the scale showed normal distribution (Otrar, Gülten \& Özkan, 2012). As a result of EFA, epistemological belief scale consisted of four-factors. The names of factors were "simple knowledge (SK)", "justification of knowledge (JK)", "innate ability (IA", and "development of knowledge (DK)". There were 11 items in the factor of SK and nine items in JK, five items in IA and four items is DK. The sample items from each factor are as follows:

- In science, all questions have one correct answer. (SK)

- Experimentation is a good way to see if something is right. (JK)

- How successful you are at school depends on how clever you are. (IA)

- Knowledge in scientific books sometimes changes. (DK)

In order to confirm the factor structure of the scale, confirmatory factor analysis (CFA) was performed by using LISREL program. Since REMSEA value (.047), Chi square/df value (2.41) and other fit indices (NFI= .93, GFI=.91, CFI=.96, RFI=.92, IFI=.96; AGFI=.90) validate the model (Kline, 2011; Jöroskog \& Sörbom, 1993), these factors were confirmed by the CFA. After the CFA, the Cronbach's Alpha reliability coefficient was found to be .846 for SK, .812 for JK, .610 for IA and .616 for DK.

\section{Semi-structured interviews}

In the qualitative data collection, semi-structured interviews were conducted with students selected from TAM and EETAM groups in order to examine the students' thoughts about the effect of TAM and EETAM on epistemological beliefs. Interviews were conducted with each student individually. During the interviews, students were asked about their opinions about TAM and EETAM. Their opinions about the effect of these models on epistemological beliefs were determined from the answers of the students. Interview questions were formed with an expert in science education and qualitative research. As a result, two separate interview 
Table 1. The dimensions of TAM and EETAM used in the intervention groups

\begin{tabular}{lll}
\hline Weeks & TAM and EETAM & EETAM \\
\hline 1 & Informing about the application of the TAM (How is claim, data, evidence and justification formed?) \\
\hline 2 & $\begin{array}{l}\text { Structure of the Atom (Evidence Cards), The Ion Concept (Theories Competing with Ideas, } \\
\text { Table of Expressions) }\end{array}$ & $\begin{array}{l}\text { Certain Knowledge, Source of Knowledge, } \\
\text { and Innate Ability }\end{array}$ \\
\hline 3 & $\begin{array}{l}\text { The Concept of Molecule (Theories Competing with Cartoons), Pure Substances (Theories } \\
\text { Competing with Stories, Table of Expressions) }\end{array}$ & Source of Knowledge \\
\hline 4 & $\begin{array}{l}\text { Common Compounds and Ions (Theories Competing with Ideas, Table of Expressions), } \\
\text { Homogeneous and Heterogeneous Mixtures (Preparation of Experiment Report) }\end{array}$ & Certain Knowledge, Omniscient Authority, \\
& Factors Affecting Dissolution Rate (Preparation of Experiment Report) & Certain Knowledge \\
\hline 6 & Separation of Mixtures (Preparation of Experiment Report) & $\begin{array}{l}\text { Certain Knowledge, Innate Ability, Source } \\
\text { of Knowledge, Simple Knowledge }\end{array}$ \\
\hline
\end{tabular}

forms were used and there were 14 questions in each form. For instance, "Which aspects of the TAM/EETAM helped you to understand the SPM unit? Explain by giving examples." This question was asked as specific to each model. The interviews were conducted by the first researcher and lasted approximately 25 minutes. All of the interviews were conducted with the interviewer in a quiet and comfortable environment and the interviews were audio-taped and then transcribed.

\section{Lesson plans}

In the research, activities prepared according to EETAM were performed in the teaching of seventh grade SPM unit in one of the experimental groups. In the other experimental group, lessons were conducted on the basis of TAM. Lesson plans of these groups were prepared by searching the literature (Erduran, 2006; Erduran \& Pabuçcu, 2012; la Velle \& Erduran, 2007). The prepared lesson plans were examined by a total of four different experts, one professor in chemistry, one associate professor and one assistant professor in chemistry education and one associate professor in argumentation. In the comparison group, the lessons are conducted in accordance with the method suggested in national science curriculum. The lesson plan was prepared for the comparison group and presented to the evaluation of three different science education experts before using in the study. The study lasted in a total of 24 teaching hours for six weeks.

\section{Intervention in the experiment groups}

Toulmin's argumentation model was used in TAM and EETAM groups. Schommer's (1990) epistemological model was used in EETAM. Table 1 shows the dimensions of TAM and EETAM used in the activities performed in the experimental groups each week.

In order to ensure that the treatment is performed as planned, the teacher was educated by the first author on how to administer the treatment two weeks before the treatment. In addition, before every session in the experimental group, the researchers and teacher met and discussed similar activities carried out in the class. Before the lessons, all instructional materials, activities and teacher guides were given to the teacher. In the first week, the first author taught the students about TAM and EETAM implementation.

Students worked in groups during the lessons. The first researcher and the course's science teacher heterogeneously distributed students in terms of their academic achievement to the groups. In Figure 1, schematic diagrams of the methods are shown. After the first consensus on subject knowledge, epistemological beliefs were incorporated by the teacher into the process, as shown in Figure 1. The key difference between EETAM and TAM is the new process of argumentation that starts with this integration. With the aid of this new argumentation, it was ensured that the students used the first argument on subject information (A0) in new argument on epistemological beliefs (A1). The argument developed in the first stage (A0) serves as data, warrant, backing or rebuttal in the new argument on epistemological beliefs (A1). For example, in the second week of the research, atom models from Democritus to the modern atomic atom theory were presented in experimental groups in story form. In the TAM and EETAM groups, the students discussed which atomic model is accepted today in the light of the information given to them in the story (AO in Figure 2). In the EETAM group, students additionally started a second discussion on the certainty and empirical nature of scientific knowledge. Students used what they had learned in the first discussion on atomic models and atomic structure to form and support their claims in the second discussion (A1 in Figure 2). In this way, discussions were held in the EETAM group regarding all the dimensions of Schommer's epistemological belief model through the intervention. As a consequence of this process, EETAM was developed. This model was shown in Figure 2. 


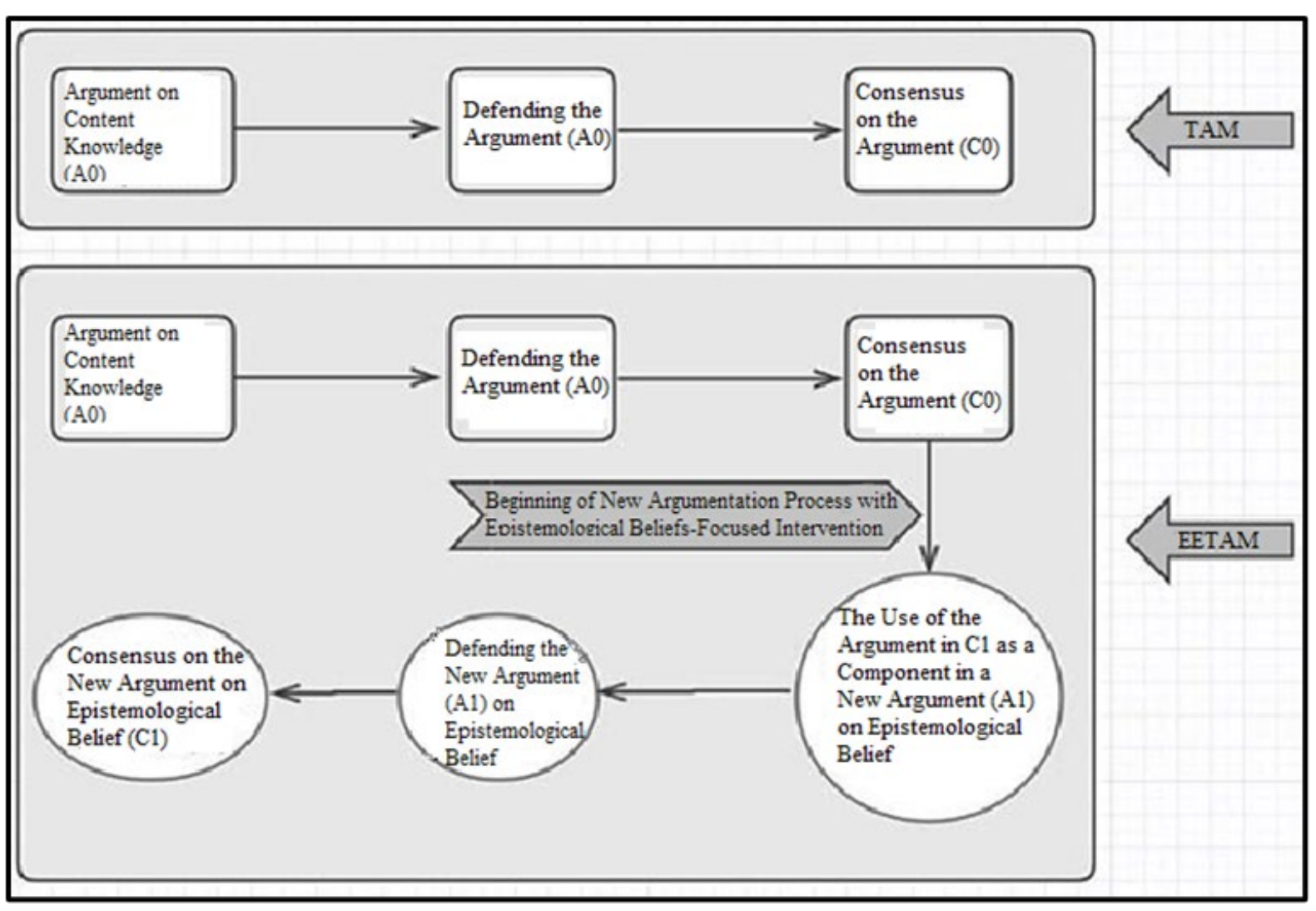

Figure 1. Schematic representation of TAM and EETAM

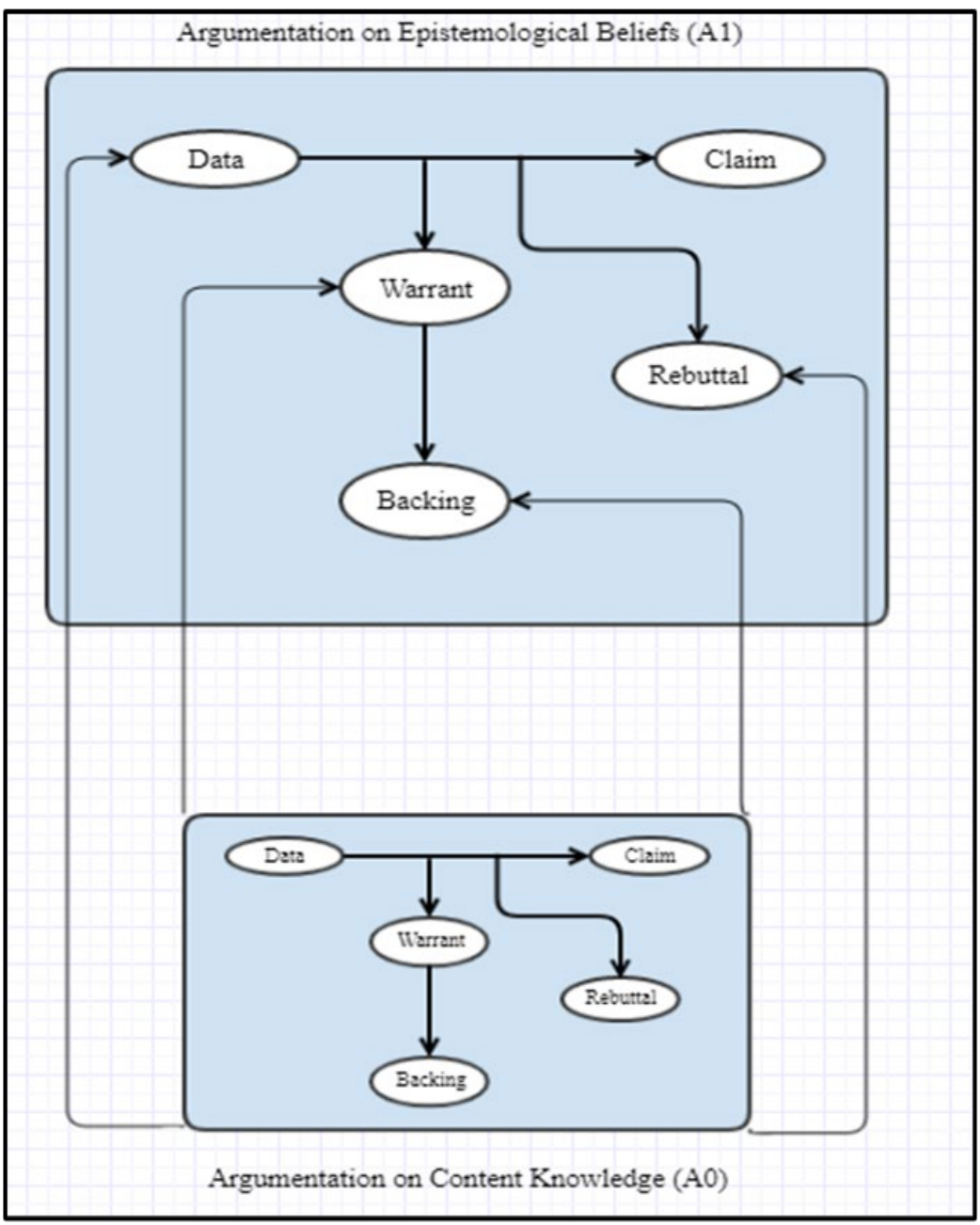

Figure 2. Epistemologically enriched Toulmin argumentation model (EETAM) 


\section{Data Analyses}

At the beginning of the study, ANOVA analysis was used to determine whether the groups were equivalent in terms of academic achievement. In addition, at the beginning of the study, the groups were compared using ANOVA to determine whether there was a difference between the epistemological beliefs of the students. At the end of the intervention, the effects of EETAM, TAM and national science curriculum on the students' epistemological beliefs were compared.

Interviews were evaluated in the qualitative section, using content analysis. In an attempt to identify codes and establish categories, each of the researchers read the transcripts and interpreted them with regard to the opinions of the participants about TAM and EETAM. In order to compare the codes, researchers held meetings, address conflicts between codes constructed when required and achieve consensus (Patton, 2002). The effects of TAM and EETAM have been classified.

\section{Power and effect size}

At the start of the research, power analysis is conducted to assess the number of participants needed to attain the desired power (Cohen et al., 2003). First, the degree of significance $(p=.05)$ was calculated in order to determine the minimum number of samples needed in the analysis. Secondly, the power of the analysis that is the probability of rejecting a false null hypothesis was considered to be 0.80 . (Hinkle et al., 1998). Finally, based on the literature, the effect size index (f2) was calculated at a medium effect size (0.15) (Cohen et al., 2003).

To measure the minimum sample size needed, the Cohen et al. (2003) formula was used. The minimum sample size to be determined for the study was 68 . The number of participants in this study was 98 , more than the minimum sample size. The study's measured power was therefore found to be between .90 and .95 . This value will be contrasted with the observed power of the analysis obtained by ANCOVA and the external validity of the generalizability of the analysis to the accessible population will be discussed.

\section{Validity and reliability}

Firstly, data collection tools were controlled by the experts for internal validity in order to understand the degree to which the researchers' comments on instruments represent reality (Creswell, 2009). Second, with direct quotes, the qualitative results were described. Thirdly, after and before the interviews, long-term interaction was provided. Finally, by posing alternative questions, the problems which the participants did not understand during the interview were explained (Lincoln \& Guba, 1985).

The research process, research design, data collection process, how the data is analyzed and interpreted is explained in depth in order to improve external validity. Furthermore, the participants were selected according to the criterion sampling and their names were coded on the basis of ethical concerns (Yıldırım \& Şimsek, 2011).

Among the researchers, a consensus was reached on the analyses performed to improve internal reliability. In addition, the results were presented without reflecting personal comments for internal reliability. A clear relationship was formed between the results of the research and the findings obtained from the research in order to improve external reliability, and it was reviewed by an expert in science education (Lincoln \& Guba, 1985).

\section{FINDINGS}

In the findings of the study, descriptive statistical analysis was started in order to understand whether the collected data were normally distributed or not. In this context, it was checked whether the mean, median and mode scores obtained from the pretest and post-test were close to each other and these values were found to be close to each other. Secondly, the kurtosis and skewness values of the data were checked. According to the results of these analyzes, it was accepted that the data of the EBS showed normal distribution. Based on these findings, it is concluded that parametric test can be used in inferential statistical analysis. The findings obtained from the descriptive statistical analysis of the pre-test and post-test of EETAM group, TAM group and comparison group are presented in Table 2.

As can be seen in Table 2; mean, mode and median values are close to each other for the pre-test and post-test scores of TAM, EETAM and comparison groups. In addition, the skewness and kurtosis scores of the groups were found to be between +2 and -2 . Therefore, it was thought that pre-test and post-test scores were distributed normally for all groups. Because the skewness and kurtosis values did not exceed the critical range and the mean, mode and median values were close to each other (George \& Mallery, 2001). 
Table 2. Findings of descriptive statistics for pre-test and post-test results

\begin{tabular}{|c|c|c|c|}
\hline Group & Statistics & Pre-test & Post-test \\
\hline \multirow{5}{*}{ EG1 } & Mean & 101.06 & 108.79 \\
\hline & Median & 102.00 & 108.50 \\
\hline & Mode & 102.00 & 109.00 \\
\hline & Skewness & -.456 & -.021 \\
\hline & Kurtosis & -.198 & -.636 \\
\hline \multirow{5}{*}{ EG2 } & Mean & 101.13 & 115.81 \\
\hline & Median & 102.50 & 116.00 \\
\hline & Mode & 102.00 & 120.00 \\
\hline & Skewness & -1.092 & -.296 \\
\hline & Kurtosis & 1.944 & .143 \\
\hline \multirow{5}{*}{ Comparison } & Mean & 106.09 & 107.00 \\
\hline & Median & 106.00 & 109.00 \\
\hline & Mode & 99.00 & 112.00 \\
\hline & Skewness & -.263 & -.551 \\
\hline & Kurtosis & -.516 & .643 \\
\hline
\end{tabular}

Table 3. ANOVA results for EBS pre-test

\begin{tabular}{ccccc}
\hline & Sum of Squares & df & Mean Square & F \\
\hline Between Groups & 536.148 & 2 & 268.074 & 1.405 \\
\hline Within Groups & 18122.954 & 95 & 190.768 & \\
\hline Total & 18659.102 & 97 & & \\
\hline
\end{tabular}

Table 4. Correlation results between pre-test and post-test results

\begin{tabular}{llc}
\hline & & \\
& & \\
Pre-test & P. Correlation & -.106 \\
\cline { 2 - 3 } & Sig. & .297 \\
\cline { 2 - 3 } & $\mathrm{N}$ & 98 \\
\hline
\end{tabular}

Table 5. Levene test results of error variance

\begin{tabular}{cccc}
\hline Levene Statistic & df1 & df2 & Sig. \\
\hline 1.769 & 2 & 95 & .176 \\
\hline
\end{tabular}

In order to determine whether there is a variable to be considered as covariance, firstly, it was checked whether there was a significant difference between the comparison and experimental groups in terms of epistemological belief scale pretest scores. In addition, covariance control was performed by calculating correlation coefficients between variables. ANOVA results regarding the pre-test scores are presented in Table 3.

As seen in Table 3, there is no difference between the groups in terms of pre-test scores ( $p=.250>.05)$. Therefore, it can be said that the groups were equivalent in terms of epistemological belief scores before the intervention. After seeing no difference between the groups in terms of pre-test scores, the correlation between the pre-test and post-test scores of the students was also examined. If an independent variable (Pre-tests) is to be controlled as a covariance, it must have a significant correlation with at least one of the dependent variables (Post-tests) (George \& Mallery, 2001). Table 4 shows the results of the correlation between the pre-test and post-test.

When the correlation results were examined, it was seen that there was no significant correlation between the pre-test and post-test scores of the epistemological belief scale. Therefore, it was not necessary to determine the pre-test results as covariance in the comparison of the post-test scores. Therefore, the post-test scores were compared using ANOVA. There are number of assumptions that must be met before applying ANOVA. Firstly, measurement level and independence of observations assumption is checked. In the study, the dependent variable was measured with the help of an interval level scale. Also, it was assumed that the students' responses to the epistemological belief scale were independent of each other. As a second assumption normality is controlled. In this context, both univariate and multivariate normality were checked. Findings of univariate normality are given in the descriptive statistics section. The multivariate normality was checked with Mahalanobis distance, and it was assumed that the data were normally distributed because there was no extreme value in the study. Lastly, Levene test was used to test the assumption of homogeneity of variances (Table 5). The significance values higher than .05 indicate that the assumption of equality of variance has not been violated.

As shown in Table 5, there is no violation of the assumption of equality of variance for EBS posttest scores. After controlling the assumptions, ANOVA was used to determine whether there was a significant difference between the comparison and experimental groups in terms of the post-test scores of the participants. The analysis was carried out and the results were given in Table 6. 
Table 6. ANOVA results for EBS post-test

\begin{tabular}{ccccc}
\hline & Sum of Squares & df & Mean Square & F \\
\hline Between Groups & 1394.066 & 2 & 697.033 & 3.593 \\
\hline Within Groups & 18428.434 & 95 & 193.984 & \\
\hline Total & 19822.500 & 97 & & \\
\hline
\end{tabular}

Table 7. Pairwise comparison results of ANOVA

\begin{tabular}{|c|c|c|c|c|c|c|c|}
\hline & \multirow{2}{*}{ (I) Group } & \multirow{2}{*}{ (J) Group } & \multirow{2}{*}{$\begin{array}{c}\text { Mean Difference } \\
(\mathrm{I}-\mathrm{J})\end{array}$} & \multirow{2}{*}{ Std. Error } & \multirow{2}{*}{ Sig. } & \multicolumn{2}{|c|}{ 95\% Confidence Interval } \\
\hline & & & & & & Lower Bound & Upper Bound \\
\hline \multirow{6}{*}{ Tukey } & \multirow{2}{*}{ TAM } & EETAM & -7.018 & 3.430 & .107 & -15.19 & 1.15 \\
\hline & & Comparison & 1.794 & 3.430 & .860 & -6.37 & 9.96 \\
\hline & \multirow{2}{*}{ EETAM } & TAM & 7.018 & 3.430 & .107 & -1.15 & 15.19 \\
\hline & & Comparison & $8.813^{*}$ & 3.482 & .034 & .52 & 17.10 \\
\hline & \multirow{2}{*}{ Comparison } & TAM & -1.794 & 3.430 & .860 & -9.96 & 6.37 \\
\hline & & EETAM & $-8.813^{\star}$ & 3.482 & .034 & -17.10 & -.52 \\
\hline
\end{tabular}

Table 8. Codes and categories regarding EETAM group

\begin{tabular}{ccc}
\hline Categories & Codes & Participants \\
\hline \multirow{2}{*}{ Certain knowledge } & Tentativeness of knowledge in books & Alp, Asu, Eren, Naz, Gül \\
\cline { 2 - 3 } Omniscient Authority & Questioning what is learned & Asu \\
\cline { 2 - 3 } & The role of experiment and observation & Eren, Naz \\
\hline Innate Ability & Importance of hard work & Alp, Gül, Ahu \\
\hline
\end{tabular}

As seen in Table 6, there is a statistically significant difference between comparison and experimental groups in terms of dependent variable $(F(2,95)=3.593 ; p<.05)$. A pairwise comparison was conducted and the results are shown in Table 7 .

While there was a statistically significant difference between EETAM group and comparison group ( $p=.034<.05)$, there was no statistically significant difference between TAM and comparison group $(p=.860>.05)$ and between EETAM and TAM group $(p=.107>.05)$ in terms of posttest scores.

\section{Findings of Qualitative Data}

In this section, the findings of the interviews conducted to determine the opinions of students from TAM and EETAM groups about the effects of TAM and EETAM on epistemological beliefs are presented. For this purpose, transcribed interview audio recordings were subjected to content analysis. In the interviews conducted with students in the TAM group, it was concluded that the model had an effect on some factors such as academic achievement, peer learning, active participation in the lesson, but no findings were found regarding the effect of TAM on epistemological beliefs. Since the student's views on the effect of TAM on some variables other than epistemological beliefs are not in the scope of this article, no information about these effects is given in this section. Therefore, only the findings obtained from the opinions of the students in the EETAM group are included in Table 8.

Based on the opinions of the students in EETAM group, findings related to certain knowledge, omniscient authority and innate ability dimensions of epistemological beliefs were obtained. The certain knowledge category is determined based on the participants thought about the tentative nature of the scientific knowledge. In this regards participants mostly emphasized the tentativeness of knowledge in books. In this context, Alp expressed his ideas regarding the tentativeness of knowledge in the certain knowledge category as follows;

"Alp: There should be discussions (about epistemological beliefs) because not every book is true, for example, is it true or can knowledge in books change? There must be such discussions because everything can change at any moment."

Also, under certain knowledge category, a participant (Asu) stated that after science lessons conducted using EETAM, she became aware of the fact that there is no single and certain truth in science and started to search alternative explanation about what she learned in lessons. She explained her thoughts as follows;

"Asu: I can now ask questions in my mind when we start to a new topic, for example, I ask different views about the subject to the teacher."

The second category derived from interview findings is the omniscient authority category. This category is formed based on the views of the participants regarding the source of scientific knowledge. In the context, participants emphasized the role of experimentation and observation in the production of scientific knowledge. Eren, one of the participants, expressed his opinion on the role of experimentation and observation in the change of knowledge with the following dialogue with the researcher;

"Researcher: Is the scientist a source of knowledge or is it more accurate to conduct experiments and observations? We have had such discussions in lessons. What did you learned from these discussions?

Eren: For example, when scientists told a subject directly, I thought it was unchangeable, but I found out that it was not so, I learned that ideas and observation could change those ideas. 
Researcher: How did you come up with this idea? Why has your mind changed? What was the role of the discussions in this?

Eren: Because we were having discussions. Our ideas changed when we discussed. I thought scientists could change their minds like that. After discussing, experimenting and observing, I came to this conclusion."

Participants' thoughts on the process of producing scientific knowledge also provide information about the fact that the source of knowledge is experiments and observations rather than omniscient science authorities. For example, Naz expressed her opinion as follows;

"Naz: If we discuss among ourselves (in lessons), for example, how do scientists learn? For example, astronauts go to space and search. Then they give us when they come to Earth. We learn about space."

The last category derived from interview findings is named as innate ability. This category is based on the participants' views on the debate about whether innate abilities or hard work is more important to be successful. In this regard, Alp, Gül ans Ahu stated their thought on the behalf of hard work in this discussion. In this context these participants stated that they believe in the importance of hard working more than innate abilities such as intelligence in order to be successful in science. For example, Ahu expressed her opinions on this subject by the following dialogue;

"Researcher: Have you changed your thoughts about epistemological beliefs?

Ahu: I have not changed in others (dimensions), but my thoughts have changed, for example, that learning depends on intelligence or work. I thought it was a bit dependent on intelligence, but now I learned that working is also important."

\section{RESULTS AND DISCUSSION}

According to the quantitative and qualitative results obtained in the study, it can be said that EETAM is more effective than TAM and the current science curricula in developing students' epistemological beliefs. Thus, application of the Toulmin argumentation model without explicitly emphasizing epistemological beliefs does not have a significant effect on students' epistemological beliefs. In this context, the findings of the study support the view that explicit teaching approach is more effective in developing epistemological beliefs than the approach that assumes that epistemological beliefs will develop as a result of natural processes in the course. In this sense, the research results are compatible with many studies in the literature (Brownlee et al., 2001; Muis \& Duffy, 2013).

When the similar studies in the literature about the teaching of epistemological beliefs with an explicitly reflective approach are examined, no study has been found where the Toulmin argumentation model is applied in an epistemologically enriched form and its effect on epistemological beliefs is examined. However, it is seen in the literature that when the epistemologically enriched models or the lessons enriched with the discussions about epistemological beliefs were examined, it was concluded that the students' epistemological beliefs developed as a result of these courses (Bektaş, 2011; Muis \& Duffy, 2013; Yerdelen Damar, 2013). For example, in a current research, Shi (2020) tested the effect of explicit teaching of philosophy of science with subject knowledge just as current research and the researcher reported that explicit teaching of philosophy of science helped students to develop more sophisticated understanding about science and the relationship between science, technology and society.

Among the researchers in the literature, Bektaş (2011) stated that he encountered difficulties in changing epistemological beliefs. As one of these difficulties, the issue of time was discussed and it was stated that long periods were needed to change the epistemological beliefs in the desired direction. According to the results of the present study, it can be said that a six-week intervention is not sufficient for a significant difference in epistemological belief scores of TAM and EETAM groups.

Muis and Duffy (2013) examined the effect of education with epistemologically supported content on students' epistemological beliefs. The researcher examined the effect of the content prepared in the study by comparing it with a comparison group and followed the change week by week during the intervention process. As a result of the intervention, it was seen that there was a difference between the groups in terms of justification of knowledge, access to knowledge, simplicity of knowledge and certainty of knowledge, but no difference was found between groups in terms of source of knowledge. As a result of the weekly analysis of the changes, it was found that the first change was in the simple knowledge, certain knowledge and attainability of truth dimensions (8. Week), and the latest change was in the source of knowledge dimension (15. Week). Based on this result, the researcher stated that it is necessary to expose students to discussions and use learning strategies that cause them to doubt their current beliefs in order to realize the change in epistemological beliefs. In the present study, in the EETAM group, the teacher explicitly led the students to think and discuss about epistemological beliefs and asked students to produce reasons to support their claims. Therefore, it can be said that these debates and justifications developed the epistemological beliefs of the students in EETAM group. Muis et al. (2006) suggested that the development of individuals' beliefs is a result of the interaction between the individual and the environment. Accordingly, social interactions in a classroom are particularly key to promoting change through discussion (Bendixen, 2002; Cited in Muis, Bendixen \& Haerle, 2006). In this context, it can be said that the epistemological beliefs of the students have developed as a result of in-group discussions, inter-group discussions and studentteacher interactions regarding epistemological beliefs. Supporting this result, research results show that cooperative learning techniques are effective in development of epistemological beliefs (Gok, 2018). Also, as the interaction between individuals in 
learning enviromnts incrase, effect of the technique also increases (Şimşek \& Baydar, 2019). In the TAM and comparison groups, it can be concluded that there is no change since these discussions and thinking processes are not directly involved.

Another reason of the difference in epistemological beliefs in favor of EETAM group can be the writing activities in the context of explicit discussions. Students filled the activity sheets during activities, wrote down their claims, warrants, qualifiers or rebuttals and formed their arguments. After that they defended their arguments against other groups. There are results in literature that writing activities improve student's epistemological beliefs (Atasoy \& Küçük, 2020; Brownlee et al., 2011). While the students are expressing their thought in a written form, they have chance to interpret and be aware of their existing opinions, feelings and experiences about knowledge and learning (Atasoy \& Küçük, 2020). This process result in a development in students epistemological beliefs.

In another study, Yerdelen Damar (2013) examined the effect of the epistemological and metacognitive enriched 7E method on the students' epistemological beliefs and stated that the method developed the students' epistemological beliefs towards physics course more than the traditional method. Therefore, both the results of the present study and the studies in the literature (Bektas, 2011; Brownlee et al., 2001; Muis \& Duffy, 2013; Yerdelen Damar, 2013) shows that explicit teaching improves epistemological beliefs.

In the literature, there are findings that question-based learning approaches such as argumentation can be effective in developing epistemological beliefs (Caukin, 2010; Driver, Newton \& Osborne, 2000; Kaynar, Tekkaya \& Çakıroğlu, 2009; Kuhn, 1993; Ryu \& Sandoval, 2011; Tucel, 2016; Wu \& Wu, 2011). Among these studies, Tucel (2016) examined the effect of argument-based science learning approach on students' epistemological beliefs. As a result of the intervention, it has been concluded that students have developed significantly in the development of knowledge and justification of knowledge dimensions of epistemological beliefs. Similarly; Kaynar et al. (2009) concluded that the 5E model led to a significant change in the epistemological beliefs of sixth grade students. However, it is seen in the literature that there are also studies applying an inquiry-based approach but could not provide a significant change in students' epistemological beliefs. In one of these studies, Caukin (2010) investigated the effect of argument-based science learning approach on epistemological beliefs of chemistry students. In this study, although the argument-based science learning approach developed the students' epistemological beliefs, this development was not significant. Similarly, Wu and Wu (2011) reported that even though the fifth grade students could develop more advanced understanding of the nature of science as a result of questioning activities implemented to improve students' epistemological beliefs, the vast majority of students did not develop their epistemological beliefs. Based on the current research and related studies reporting different results in the literature, it can be said that the explicitly reflective approach is more effective than inquiry-based teaching approaches in developing students' epistemological beliefs.

\section{CONCLUSION}

As a conclusion, EETAM was found to be more effective in the development of students' epistemological beliefs than TAM and the method suggested in the current science program. Also, it was determined that TAM did not make a difference compared to the method suggested in Turkish science curricula. When EETAM and TAM were compared, it was seen that there was no difference between these two models in terms of developing epistemological beliefs. When the qualitative findings obtained in the study were examined, no finding was found about epistemological beliefs in the TAM group, but it was found that the EETAM developed epistemological beliefs in the EETAM group.

\section{RECOMMENDATIONS}

In this section, suggestions are made for researchers and science teachers based on the findings of the study. These recommendations can be listed as follows.

(1) The results of the study showed that the explicit teaching of epistemological beliefs is more effective compared to implicit teaching. Therefore, explicit teaching of epistemological beliefs should be given priority.

(2) In this study, the effect of EETAM on epistemological beliefs was investigated. Similarly, it can be investigated how the epistemologically enrichment of other teaching methods known and used in the literature affects epistemological beliefs.

(3) While teaching teacher candidates how to use the teaching methods in the teacher training programs, it is recommended to teach how to integrate the activities and discussions which will develop the students' epistemological beliefs to these methods.

(4) The results of the study showed that within and between groups discussions conducted as part of TAM and EETAM are effective in development of epistemological beliefs. Therefore, this type of discussions sessions should find more place in science lessons.

Author contributions: All authors have sufficiently contributed to the study, and agreed with the results and conclusions.

Funding: This research did not receive any specific grant from funding agencies in the public, commercial, or not-for-profit sectors.

Declaration of interest: The authors declare that they have no conflict of interest. 


\section{REFERENCES}

Akkuş, R., Günel. M., \& Hand. B. (2007). Comparing an inquiry-based approach known as the science writing heuristic to traditional science teaching practices: Are there differences? International Journal of Science Education, 29(14), $1745-1765$. https://doi.org/10.1080/09500690601075629

Atasoy, S., \& Küçük, O. (2020). Development of eighth grade students' epistemological beliefs through writing-to-learn activities. Journal of Science Learning, 3(2), 57-66. https://doi.org/10.17509/jsl.v3i2.20573

Bektas, O. (2011). The effect of 5 E learning cycle model on tenth grade students' understanding in the particulate nature of matter, epistemological beliefs and views of nature of science (Unpublished doctoral dissertation). Middle East Technical University. Ankara, Turkey.

Boz, Y., Aydemir, M., \& Aydemir, N. (2011). 4th. 6th. and $8^{\text {th }}$ grade Turkish elementary students' epistemological beliefs. Elementary Education Online, 10(3), 1191-1201.

Brownlee, J., Petriwskyj, A., Thorpe, K., Stacey, P., \& Gibson, M. (2011). Changing personal epistemologies in early childhood preservice teachers using an integrated teaching program. Higher Education Research \& Development, 30(4), 477-490. https://doi.org/10.1080/07294360.2010.518952

Brownlee, J., Purdie, N., \& Boulton-Lewis, G. (2001). Changing epistemological beliefs in pre-service teacher education students. Teaching in higher education, 6(2), 247-268. https://doi.org/10.1080/13562510120045221

Caukin, N. S. (2010). Science Writing Heuristic: A writing-to-learn strategy and its effect on students'science achievement, science selfefficacy, and scientific epistemological view (Unpublished doctoral dissertation), Tennessee State University.

Cohen, J., Cohen, P., West, S. G., \& Aiken, L. S. (2003). Applied multiple regression/correlation analysis for the behavioral sciences (3rd Ed.). Lawrence Erlbaum Associates.

Creswell, J. W. (2009). Research design, qualitative, quantitative, and mixed methods approaches (3rd Ed.). SAGE Publications.

Creswell, J. W., \& Plano Clark, V. L. (2015). Mixed Methods Researches: Designing and Conducting [Karma yöntem araştırmaları: Tasarımı ve yürütülmesi] (Translated 2nd Ed.) (Y. Dede \& S. B. Demir, Trans. Ed.). Anı Publishers.

de Oliveira Gabriel, V., Panisson, A. R., Bordini, R. H., Adamatti, D. F., \& Billa, C. Z. (2020). Reasoning in BDI agents using Toulmin's argumentation model. Theoretical Computer Science, 805, 76-91. https://doi.org/10.1016/j.tcs.2019.10.026

Deryakulu, D., \& Büyüköztürk, Ş. (2005). The re-examination of the epistemological beliefs questionnaire's factor structure: comparing epistemological beliefs in terms of gender and program type. Eurasian Journal of Educational Research, 18, 57-70.

Driver, R., Newton, P., \& Osborne, J. (2000). Establishing the norms of scientific argumentation in classrooms. Science Education, 287-312. https://doi.org/10.1002/(SICI)1098-237X(200005)84:3<287::AID-SCE1>3.0.CO;2-A

Elby, A. (2001). Helping physics students learn how to learn. American Journal of Physics. Physics Education Research Supplement, 69(7), S54-S64. https://doi.org/10.1119/1.1377283

Elby, A., \& Hammer, D. (2010). Epistemological resources and framing: A cognitive framework for helping teachers interpret and respond to their students' epistemologies. In L. D. Bendixen \& F. C. Feucht (Eds.). Personal epistemology in the classroom: Theory, research, and implications for practice (pp. 409-434). Cambridge University Press. https://doi.org/10.1017/CB09780511691904.013

Erduran, S. (2006). Promoting ideas, evidence and argument in initial science teacher training. School Science Review, 87(321), 4550.

Erduran, S. (2007). Special editorial: Argument, discourse and interactivity. School Science Review, 88(324), 29-30.

Erduran, S., \& Pabuccu, A. (2012). Bonding chemistry and argument: teaching and learning argumentation throught chemistry stories. University of Bristol.

Evagorou, M., \& Osborne, J. (2009). Dimensions of successful argumentation [Paper presentation]. 8th European Science Education Research Association (ESERA) Annual Conference 31 August-4 September, Istanbul, Turkey.

George, D., \& Mallery, P. (2001). SPSS for Windows. Step by step (3rd Ed.). Allyn \& Bacon.

Giri, V., \& Paily, M. U. (2020). Effect of collaborative scientific argumentation strategy on achievement in biology among 12 th grade students. Journal of Critical Review, 7(3), 344-353. https://doi.org/10.31838/jcr.07.03.67

Gok, T. (2018). The evaluation of conceptual learning and epistemological beliefs on physics learning by think-pair-share. Journal of Education in Science, Environment and Health (JESEH), 4(1), 69-80. https://doi.org/10.21891/jeseh.387489

Hammer, D., \& Elby, A. (2002). On the form of a personal epistemology. Personal epistemology: The psychology of beliefs about knowledge and knowing, 169-190.

Hill, R. (1998). What sample size is "enough" in internet survey research. Interpersonal Computing and Technology: An electronic journal for the 21st century, 6(3-4), 1-12.

Hinkle, D. E., Wiersma, W., \& Jurs, S. G. (1998). Correlation: a measure of relationship. Applied statistics for the behavioral sciences, 4, 105-131.

Hitchcock, D. (2005). Good reasoning on the toulmin model. Argumentation, 19(3), 373-391. https://doi.org/10.1007/s10503-005$4422-y$ 
Hofer, B. K. (2002). Personal epistemology as a psychological and educational construct: An introduction. In B. K. Hofer \& P. R. Pintrich (Eds.), Personal epistemology: The psychology of beliefs about knowledge and knowing, (3-14). Routledge. https://doi.org/10.4324/9781410604316

Hofer, B. K., \& Pintrich, P. R. (2012). Personal epistemology: The psychology of beliefs about knowledge and knowing. Routledge. https://doi.org/10.4324/9780203424964

Hofer, B. K., \& Pintrich, P. R. (1997). The development of epistemological theories: Beliefs about knowledge and knowing and their relation to learning. Review of Educational Research, 67, 88-140. https://doi.org/10.3102/00346543067001088

Hogan, K. (1999). Relating students' personal frameworks for science learning to their cognition in collaborative contexts. Science Education, 83(1), 1-32. https://doi.org/10.1002/(SICI)1098-237X(199901)83:1<1::AID-SCE1>3.0.CO;2-D

Jimenez-Aleixandre, M. P., \& Erduran, S. (2007). Argumentation in science education: An overview. In S. Erduran \& M. P. JimenezAleixandre (Eds.), Argumentation in science education: Perspectives from classroom-based research (pp. 3-28). Springer. https://doi.org/10.1007/978-1-4020-6670-2_5

Jöroskog, K., \& Sörbom, D. (1993). Lisrel 8: structural equation modeling with the simplis command language. Scientific Software International, Inc.

Kaynar, D., Tekkaya, C., \& Çakıroğlu, J. (2009). Effectiveness of 5e learning cycle instruction on students' achievement in cell concept and scientific epistemological beliefs. Hacettepe Üniversitesi Eğitim Fakültesi Dergisi, 37(37), 96-105.

Kitcher, P. (1988). The child as parent of the scientist. Mind and Language, 3(3), 215-228. https://doi.org/10.1111/j.14680017.1988.tb00144.x

Kızılgünes, B., Tekkaya, C., \& Sungur, S. (2009). Modeling the relations among students' epistemological beliefs, motivation, learning approach and achievement. The Journal of Educational Research, 102(4), $243-255$. https://doi.org/10.3200/JOER.102.4.243-256

Kline, R. B. (2011). An easy guide to factor analysis. The Guilford Press

Kuhn, D. (1993). Science as argument: Implications for teaching and learning scientific thinking. Science Education, 77(3), $319-337$. https://doi.org/10.1002/sce.3730770306

Kuhn, D. (2005). Education for thinking. Harvard University Press.

la Velle, L. B., \& Erduran, S. (2007). Argument and developments in the science curriculum. School Science Review, 88(324), 31.

Lincoln, Y. S., \& Guba, E. G. (1985). Naturalistic inquiry. Sage. https://doi.org/10.1016/0147-1767(85)90062-8

Lising, L., \& Elby, A. (2005). The impact of epistemology on learning: A case study from introductory physics. American Journal of Physics, 73(4), 372-382 https://doi.org/10.1119/1.1848115

Magalhães, A. L. (2020). Teaching how to develop an argument using the Toulmin model. International Journal of Multidisciplinary and Current Educational Research (IJMCER), 2(3), 01-07.

MoNE. (2013). Primary (3, 4, 5, 6, 7 and 8 grades) science education programs. Ankara: Board of Education and Discipline. http://ttkb.meb.gov.tr/program2.aspx?islem=1\&kno=213

MoNE. (2018). Science education program. Ankara: Board of Education and Discipline. http://mufredat.meb.gov.tr

Muis, K. R., \& Duffy, M. C. (2013). Epistemic climate and epistemic change: Instruction designed to change students' beliefs and learning strategies and improve achievement. Journal of Educational Psychology, 105(1), 213. https://doi.org/10.1037/a0029690

Muis, K. R., Bendixen, L. D., \& Haerle, F. C. (2006). Domain-generality and domain-specificity in personal epistemology research: Philosophical and empirical reflections in the development of a theoretical framework. Educational Psychology Review, 18(1), 3-54. https://doi.org/10.1007/s10648-006-9003-6

Munford, D., \& Zembal-Saul, C. (2002). Learning Science through Argumentation: Prospective Teachers' Experiences in an Innovative Science Course. National Association for Research in Science Teaching. New Orleans. LA.

Otrar, M., Gülten, D. Ç., \& Özkan, E. (2012). Developing a learning styles scale for primary school students (AÖS-I). Journal of Research in Education and Teaching, 1(2), 305-318.

Özkan, Ş. (2008). Modeling elementary students'science achievement: the Interrelationships among epistemological beliefs, learning approaches and self-regulated learning strategies (Doctoral thesis). Middle East Technical University, Ankara.

Pamuk, S. (2014). Multilevel analysis of students' science achievement in relation to constructivist learning environment perceptions, epistemological beliefs, self-regulation and science teachers' characteristics (Unpublished master's thesis). Gazi University, Ankara.

Patton, M. Q. (2002). Qualitative research and evaluation methods (3rd Ed.). Sage.

Pera, M. (1994). The discourses of science. University of Chicago Press.

Perry, W. G. (1968). Patterns of development in thought and values of students in a liberal arts college a validation of a scheme. Health education. Harvard University.

Redish, E. F., \& Hammer, D. (2009). Reinventing college physics for biologists: Explicating an epistemological curriculum. American Journal of Physics, 77(7), 629-642. https://doi.org/10.1119/1.3119150 
Rosenberg, S. A., Hammer, D., \& Phelan, J. (2006). Multiple epistemological coherences in an eighth-grade discussion of the rock cycle. Journal of the Learning Sciences, 15(2), 261- 292. https://doi.org/10.1207/s15327809jls1502_4

Ryu, S., \& Sandoval, W. (2011). Improvements to elementary children's epistemic understanding from sustained argumentation. Science Education, 96(3), 488-526. https://doi.org/10.1002/sce.21006

Sandoval, W. A. (2003). Conceptual and epistemic aspects of students' scientific explanations. The Journal of the Learning Sciences, 12, 5-51. https://doi.org/10.1207/S15327809JLS1201_2

Sandoval, W. A., \& Morrison, K. (2003). High school students' ideas about theories and theory change after a biological inquiry unit. Journal of Research in Science Teaching, 40, 369-392. https://doi.org/10.1002/tea.10081

Sandoval, W. A., Enyedy, N., Redman, E. H., \& Xiao, S. (2019). Organising a culture of argumentation in elementary science, International Journal of Science Education, 41(13), 1848-1869. https://doi.org/10.1080/09500693.2019.1641856

Saylan Kirmizigul, A., \& Bektas, O. (2019). Investigation pre-service teachers' epistemological beliefs. Cypriot Journal of Educational Sciences, 14(1), 146-157. https://doi.org/10.18844/cjes.v14i1.3759

Schommer, M. (1993). Epistemological development and academic performance among secondary students. Journal of Educational Psychology, 85(3), 406. https://doi.org/10.1037/0022-0663.85.3.406

Schommer, M. (1990). Effects of beliefs about the nature of knowledge on comprehension. Journal of Educational Psychology, 82(3), 498-504. https://doi.org/10.1037/0022-0663.82.3.498

Schraw, G., Bendixen, L. D., \& Dunkle, M. E. (2002). Development and validation of the Epistemic Belief Inventory (EBI). In B. K. Hofer \& P. R. Pintrich (Eds.). Personal epistemology: The psychology of beliefs about knowledge and knowing (pp. 261-275). Lawrence Erlbaum Associates. https://doi.org/10.4324/9781410604316-22

Shi, X. (2020). Using explicit teaching of philosophy to promote understanding of the nature of science. Science \& Education, 1-32. https://doi.org/10.1007/s11191-020-00173-z

Şimşek, U., \& Baydar, A. (2019). Impact of jigsaw and teams-games tournaments (TGT) on social studies preservice teachers' epistemological beliefs. International Online Journal of Education and Teaching (IOJET), 6(2), 405-414.

Tabachnick, B. G., \& Fidell, L. S. (2013). Using multivariate statistics. Allyn \& Bacon/Pearson Education.

Toulmin, S. E. (2003). The uses of argument. Cambridge University Press. https://doi.org/10.1017/CBO9780511840005

Tsai, C. C. (1998). An analysis of scientific epistemological beliefs and learning orientations of Taiwanese eighth graders. Science Education, 82, 473-489. https://doi.org/10.1002/(SICI)1098-237X(199807)82:4<473::AID-SCE4>3.0.CO;2-8

Tucel, S. T. (2016). Exploring the effects of science writing heuristic (SWH) approach on the eighth grade students' achievement, metacognition and epistemological beliefs (Unpublished master's thesis). Gazi University, Ankara.

Wu, H. K., \& Wu, C. L. (2011). Exploring the development of fifth graders' practical epistemologies and explanation skills in inquirybased learning classrooms. Research in Science Education, 41(3), 319-340. https://doi.org/10.1007/s11165-010-9167-4

Yerdelen Damar, S. (2013). The effect of the instruction based on the epistemologically and metacognitively improved 7e learning cycle on tenth grade students' achievement and epistemological understandings in physics (Unpublished doctoral dissertation). Middle East Technical University, Ankara, Turkey.

Yıldırım, A., \& Şimşek, H. (2018). Qualitative research methods in the social sciences. Seçkin Publishing. 